\title{
Public participation and public services in British liberal democracy: Colin Ward's anarchist critique
}

\author{
Peter Wilkin \\ School of Social Sciences, Brunel University, Uxbridge UB8 3PH, England; \\ e-mail: peter.wilkin@brunel.ac.uk

\section{Carole Boudeau} \\ HaCIRIC, School of Construction Management and Engineering, University of Reading, \\ Reading RG6 6AW, England; e-mail: c.boudeau@reading.ac.uk \\ Received 12 March 2013; in revised form 14 February 2014
}

\begin{abstract}
The aim of this paper is to set out a critique of the prevailing academic and government accounts of 'public participation'. This critique is drawn from the work of the British anarchist Colin Ward, which we argue is significant because it provides an alternative to state-led or market-led models of public participation. Both of the latter models subject individuals to external forms of authority (state or market). By contrast, Ward reminds us that the working-class tradition of free and autonomous associations, illustrated notably by the friendly societies, established a different understanding of public participation, one which presupposes the actual running and maintaining of the very services that the public relied upon through the key values of mutual aid and self-help. We describe the nature of these associations and suggest that, historically, they have been the most accomplished alternatives to state-led and market-led approaches to public participation.
\end{abstract}

Keywords: public participation, public services, Colin Ward, self-help, mutual aid, friendly societies

\section{Introduction}

Since the election of a Labour government in 1997, there has been an accelerated commitment to promoting public participation in the planning and delivery of public services in the UK. Indeed, around 14 million people took part in such activities in 2001 alone (Bradshaw, 2008; Clarence and Painter, 1998; Innes and Booker, 2004; Lane, 2000; Lowndes and Sullivan, 2002, pages 51-57). This trend has been extended by the Coalition government elected in 2010, which has embraced ideas of voluntary activity and association on the part of the public in support of the reform of public services. The move towards encouraging public participation in public services is now a general trend in liberal democracies, and a number of reasons are cited for this which include: a concern with a 'democratic deficit', the perceived lack of legitimacy of government policy, the need to engage an apathetic public in democratic processes and the need to reform and render more efficient public services (Conrad et al, 2011; Fung, 2006; Lewis et al, 2005; Martin, 2008, page 35; Rowe and Frewer, 2004; M Taylor, 2006).

The aim of this paper is to set out a critique of the prevailing academic and government accounts of 'public participation'. This critique is drawn from the work of the British anarchist Colin Ward who focused on the nature of public participation in design, planning, and the provision of services including housing, education, and health care. The significance of Ward's ideas for current debates about public participation is that they provide a contrast to and critique of state-led or capitalist market-led models of public participation. It is these two models that dominate the academic literature, think-tank proposals, and government reforms of public services. Ward's work clarifies how contemporary debates on public participation, 
often presented as being in opposition to each other in the form of consumer-led or citizen-led approaches, are in fact both parts of normal liberal democratic discourse and reflective of an instrumental view of public participation and social policy. In effect, both consumer-led and citizen-led models subordinate the role and indeed their conception of 'the public' to an external authority, be it the state or the market (Clarke, 2005). By contrast, Ward reminds us how autonomous and voluntary working-class associations have and continue to provide services to their members that have been directly under their own control rather than that of the market or the state. As the new right commentator David Green (1985, page 1) noted, the Victorian age was the era of working-class mutual aid. These ideas and practices of mutual aid and self-help as found in autonomous working-class associations are important at a time when the meaning of public participation and reform of the public services is central to British social policy. They offer a genuinely different way of thinking about how public services can be organised outside of the state and the market.

In addition to this, there are other reasons for taking Ward's work seriously and reflecting on his account of 'the public'. There is a danger of viewing the examples Ward writes about as nostalgia for a golden age that has no bearing on contemporary debates or ways of living. This is far from the case, however. What Ward's account of anarchism and the public makes clear is that the struggle by individuals and communities to extend the realm of free and autonomous activity is a persistent factor of history, as much so today as it was in the 19th and early 20th centuries. It is not, of course, the only one. At the same time people have also constructed hierarchical and authoritarian institutions that take power and control away from them and place it in the hands of authorities of various kinds. The historical examples that Ward talks about reflect some of the high points in British culture of this libertarian tendency towards free and autonomous self-organisation, but they also highlight the ways in which the state and the market have gained authority and power over these practices. However, as Ward makes abundantly clear, social life remains possible in spite of the extension of the state and the market over such activities rather than because of them, and his work is a testament to the myriad examples of individuals and groups attempting to act in this way and to constitute relationships that are voluntary, free, and autonomous. As the American anthropologist Scott (2012) notes, echoing Ward:

"forms of informal cooperation, and action that embody mutuality without hierarchy are the quotidian experience of most people. Only occasionally do they embody implicit or explicit opposition to state law and institutions. Most villages and neighbourhoods function precisely because of the informal, transient networks of coordination that do not require formal organisation, let alone hierarchy" (Scott, 2012, page xxi).

And by extension it should also be stressed that this tendency towards free, voluntary, and autonomous activity is not simply a trait of British culture; far from it. As we will show, there are countless examples of just these kinds of practices around the world that continue to illustrate Ward's ideas. The fundamental dilemma for such movements, however, remains the same: is it possible to build up free and voluntary institutions and practices that can operate over the long term without their being co-opted by the state and the market?

In this paper we begin by introducing Ward and his work before situating the current debates about public participation in the broader historical context of the development of liberal democratic political culture over the course of the 20th century. In this section we set out Ward's critique of the liberal democratic polity and its provision of public services. We then provide an overview of the abandoned history of autonomous working-class associations and public services in the UK as set out in Ward's work. 


\section{Colin Ward and designing a good society}

"That means coming back to the political philosophy most consistent with sociology, namely anarchism."

Cohen (1985, page 264)

"We are groping both for a different aesthetic theory and for a different political theory ... . The missing political element is the politics of participation, of user control and of selfmanaging, self-regulating communities."

Ward (2011b, page 132)

Ward was the most significant British anarchist writer of the 20th century, and his work reached a global audience. He spent more than fifty years writing about what he saw as the twin principles of an anarchist society: mutual aid and self-help (Ward, 1985, pages 27-45; 1990a, page 9), and his legacy is a rich oeuvre of sociological observations about the way in which these principles manifest themselves as everyday practices in British culture and society (Cohen, 1985, pages 264-265). He viewed anarchism as a body of ideas from which the modern anarchist should take what was good and workable from the anarchist tradition and reject that which had failed or was morally unacceptable (Ward, 2004). Like his great influences - the Russian radical Herzen and the German anarchist Landauer-his pragmatic anarchism also led him to a rejection of insurrectionist approaches that viewed social revolution in millenarian terms:

"Many years of attempting to be an anarchist propagandist have convinced me that we win over our fellow citizens to anarchist ideas precisely through drawing upon the common experience of the informal, transient, self-organising networks or relationships that in fact make the human community possible, rather than through the rejection of existing society as a whole in favour of some future society where some different kind of humanity will live in perfect harmony" (Ward, 1973, page 5).

Thus his approach to anarchism is sometimes described as an evolutionary one whereby social change presupposes a cultural transformation of social life from which the realm of free association is gradually extended throughout society (Goodway, 2012; White, 2007). Society can always extend the boundaries of free association, and Ward said of anarchism that it is a "description of a mode of human organisation, rooted in the experience of everyday life, which operates side by side with and in spite of, the dominant authoritarian trends of our society" (1973, page 11).

\section{Mutual aid and self-help}

As mentioned, the key themes that run through his work are those of mutual aid and self-help as manifested in the activities of people attempting to work, play, and build in their lived environment. Ward was as interested in the ways that children in the city and the countryside built their own play areas as he was in the ways that members of the public sought to build their own holiday homes, houses, allotments, squats, health centres, and schools (Crouch and Ward, 1997; Ward, 1974; 1988; 1990b; 2002; 2012; Ward and Hardy, 2003; 2012; White, 2011). For Ward, mutual aid and self-help were the fundamental principles for an anarchist society and at the same time also virtuous practices that reflected social solidarity and individual independence. As he noted, the consequences of such activities were important in terms of extending the realm of free human activity and also in terms of their psychological significance for people (Honeywell, 2007, page 250). The key task for anarchists in extending the realm of free and voluntary association was to replace existing social hierarchies and the privileges that they generated for elites with a free and egalitarian social order. Out of this impulse came many of the institutions that Ward and others have discussed as examples 
of autonomous working-class associations. Self-help and mutual aid were what Ward saw reflected in everyday life:

"An anarchist society, a society which organises itself without authority, is always in existence, like a seed beneath the snow, buried under the weight of the state and its bureaucracy, capitalism and its waste, privilege and its injustices, Nationalism and its suicidal loyalties, religious differences and their superstitious separatism" (Ward, 1973, page 14).

These two principles reflect something about human nature that Ward saw as being intrinsic to a good society - that in effect people valued the things that they had taken a hand in building, running, and maintaining themselves. In short, the issue that these two principles raise is that of control over one's own life. Only when people live in a social order where they have control over their daily existence and the institutions that provide the services and goods that they need to live can they be free and, by extension, will they possess the time and inclination to participate in the organisation of that society. This idea is already borne out by research into the success and failure of existing modes of public participation in the UK (Lowndes et al, 2001). The virtues of self-help and mutual aid are self-evident for Ward, then, in that they help to create independent, practical, and free people rather than subjects of the state or the market. Through such direct action emerges a free society. In short, it is better that we do things for ourselves, wherever possible, and in free cooperation with others than it is for an external body to simply do these things for us. Thus, over the course of the 20th century the state and the market in Britain have extended their authority over most areas of social life, often in cooperation with the professions, which have become exclusive and privileged occupations of social control of public services (Ward, 1996c).

Ward's work is important to current debates about public participation as it addresses the actual lived experience of mutual aid and self-help amongst working-class communities attempting to build free forms of association and service provision outside of the state and the market. That this is even possible hardly registers in current debates about public participation in the UK, which view it largely in instrumental terms as a mechanism for legitimising state policy, increasingly in support of market mechanisms. Even the terms self-help and mutual aid, as Ward shows, have lost their original libertarian meaning and been appropriated by the political right, such as the current Coalition government in the UK. As a consequence, Baggott (2005, page 534) argues that the commitment to public participation has generated a confusing and confused discourse of 'conceptual humbug'. Understanding how and why this has happened is very important given the transformation of the welfare state that has been taking place in the UK since the late 1970s.

In contrast to current debates on public participation in public services which stress that the key question remains the distribution of resources, Ward's work shows that in fact it is the control of resources which is the key issue if public participation is not to remain an instrumental practice (Ward, 1996a, page 15). To understand how these debates have come to take the form that they do, we need to situate them within the context of the development of British liberal democracy over the course of the 20th century as an elite-led system of guided public participation about which Ward has had much to say.

\section{Public participation in liberal democracy: guiding a mass society}

It is commonplace now to note that there are crises of legitimacy in liberal democracy that are revealed in such things as nonvoting in local, national, and European elections; a lack of trust in governing institutions, and a general cynicism about politics leading to apathy on the part of the public (Corner and Pels, 2008, page 1; Doyal, 1998; Marden, 2003; Tucker, 2004). For many, the attempt to mobilise public participation has been the mechanism by which liberal democratic culture might be enriched and quality, legitimacy, and trust restored to the public 
services (House of Commons Health Committee, 2007, page 13; Lowndes et al, 2006). Leftist commentators often situate this in the context of Habermas's work on the public sphere, with participation (and deliberation) being the twin components of a revived democracy (Goode, 2005). In the UK this trend was central to the New Labour government of 1997 and has been taken on by the Coalition government since 2010. Amongst other things, this has led to a number of policies devolving decision making around local government, schooling, and the health services to community bodies and individuals, with public participation generated through a range of new institutions (Barnes et al, 2006; Design Council, 2007; Edwards, 2006; Lowndes and Sullivan, 2004, page 52). At the same time it has generated debates about the meaning and practice of participation: what is it expected to achieve? (Barnes, 1999, pages 62-63).

As former Home Secretary David Blunkett said, "Old Labour is the idea that you did things to people, New Labour is about enabling people to do things for themselves" (Williams and Windebank, 2000, page 127). The Coalition government, too, have sought to deepen this process by extending the concepts of mutual aid, voluntary association, and self-help, but in so doing they give them a meaning quite different from that which Ward ascribes them as noted earlier. Nonetheless, it is quite clear that for liberal democracy and representative government to function legitimately there is an assumption that the public must be minimally involved in the process of decision making, either through deliberation with tiers of government or in partnership with a number of public and private bodies as part of a wider incorporation of civil society (Lows and Hulatt, 2005; Newman et al, 2004, page 204; Orme et al, 2003, page 41). In this sense participatory democracy and representative democracy should be seen as complementary and part of the same process rather than being antithetical or having a problematic relationship, as some writers suggest (Barnes et al, 2004).

As an anarchist, Ward sees liberal democracy as a hierarchical social order within which elites, themselves representatives of the ruling class, compete with each other for the right to exert authority and power over society. As with other anarchists, Ward's view of a ruling class is different from that found in Marxism, recognising that the structure of hierarchy, privilege, and authority in liberal democracy is not simply rooted in economic power but includes a variety of mechanisms such as: privileged access to information and claims to authority through scientific knowledge; control of resources and the workplace; military power and the means of violence; political authority and bureaucratic authority of the state; control of consumption through the market; ownership and control of the mainstream media.

Although this process of elite competition and conflict narrowed after the end of the Cold War with the closing of ideological differences between the mainstream UK political parties, the structure of elite dominance of society through control of its governing institutions remained. Ward (2011a) suggested that hierarchy persists given the endorsement of those governed:

"I said that it is governments which make wars and prepare for wars, but obviously it is not governments alone - the power of a government, even the most absolute dictatorship, depends on the tacit assent of the governed. Why do people consent to be governed? It isn't only fear: what have millions of people to fear from a small group of politicians? It is because they subscribe to the same values as their governors. Rulers and ruled alike believe in the principle of authority, of hierarchy, of power" (page 47).

This view of elite power connects with elite theories. For many early elite theorists the elite were viewed as a natural phenomenon necessary for stable societies especially to contain the threat that the masses (the public) posed to social order; and this holds both for critics of democracy (Michels, 2001; Mosca, 2011) and for those who sought to defend it by limiting the participation of the public (Bernays, 2004; Lasswell and Lerner, 2011; Lippmann, 2010; Niebuhr, 2005). 
It is the latter group that are most deserving of our attention, as they established a way of thinking about the nature of representation in liberal democracy and the necessary limits to public participation, which are directly relevant to current debates on the reforms of public services in the UK and elsewhere. For these thinkers, writing at the beginning of the 20th century, there was an inherent weakness in any democratic system because the masses (the public) were not reliable judges of what was needed to guarantee social order and security for the state and for democracy. Therefore, in order for democracy to survive, governing elites had to learn to use new mechanisms of mass consciousness (advertising, public relations, political marketing, propaganda) as a means both to construct the meaning of the public and to direct it to elite-approved ends (Davies, 2002; Fones-Wolf, 1995; Lewis et al, 2005, page 29; Moloney, 2006; Scammell, 2008). This system of elite-led and 'guided democracy' is the one that has come to dominate and extend throughout liberal democratic countries, as has recently been argued (Hind, 2010, page 35).

Therefore, current debates about public participation have to be framed and understood within the context of the limits that such a system imposes upon democratic culture: the public responds to choices set for them by competing groups of elites. For Ward this system was the antithesis of a free society and whether the government was to be conservative, liberal, social democratic, or Marxist; it was something to be overcome and replaced by free associations.

\section{Public participation: consumer-led and citizen-led approaches}

Having provided the historical context, we can now turn to contemporary debates about public participation in the reform of UK public services. These tend to divide into two main approaches to the subject. On the one hand, consumer-led models view the public as individual consumers making choices about preferred options made available to them by professionals, the state, and private companies (Lewis et al, 2005, page 79; Martin, 2008, page 36; Orme et al, 2003, pages 42-43; Scammell, 2008); and, on the other hand, citizen-led models advocate public activity in the managing of public services, with some recent developments even talking about the need for public control of them (Baggott, 2005, page 534; Bochel et al, 2007; Martin, 2008; Newman et al, 2004). In these debates the public are engaged either as citizens or as consumers. Indeed, for Corner and Pels (2008, page 6) there is an inherent contradiction between the values of the market (consumer) and of liberal democracy (citizen).

Ward's point about the public and its relationship to the welfare state is really quite different and leads us to argue that in fact citizen and consumer are both legitimate expressions of individual identity and public engagement in a liberal democracy. Indeed, they are the fundamental forms of identity bestowed upon individuals in liberal democratic cultures: we are both citizens and consumers. So there can be no definitive argument that one form of identity is more legitimate than another when it comes to public services. What Ward alerts us to and what is crucial here is that both approaches view public participation in instrumental terms. The public is mobilised by the state, often under the guise of devolving power or empowering a community, for a particular end, and that end is to help restore the legitimacy of the state itself, whether in its direct provision of public services or through market mechanisms (Burnham, 2001, page 140; Ward, 1973, pages 110-125). The role of the public is guided (and constructed) to fulfil these ends. Ward commented on the idea of community 'empowerment' with regard to a $\mathrm{BBC} 2$ documentary on a financial crisis at London Zoo in the 1980s when one of the directors of the zoo explained the necessity for empowering his workforce because "once you've given them empowerment, you've got them in the grinder" (Ward, 1996a, page 77). 
The emphasis placed by government policy on the nature of public service reform will no doubt shift according to the particular constellation of governing elite political forces, but in essence such reforms always view the public as a body to be mobilised and directed. Indeed, inviting the public to participate in the management and reform of public services enables:

(1) The government and the state to undermine the professions and their pay, terms, and conditions of work by subjecting them to public criticism and new public management practices - the latter reflects the consumerist ethos of public service reforms (Exworthy and Halford, 1999; Hind, 2010, pages 87-89; Lane, 2000; Rowe and Shepherd, 2002, page 277).

(2) The state to shift public funding out of the hands of public institutions that are nominally accountable and democratic, and into the hands of private companies that are neither.

(3) The government to invite the public to discipline themselves with regard to the management of public services by approving cuts and austerity.

However, as Litva et al (2002, page 182) note, the public are very reluctant to be drawn into taking responsibility for cuts in public services through processes of public participation. Equally, officials are well aware of the political constraints they face in their attempts to mobilise public participation (Barnes et al, 2003, page 395). Nonetheless, it is a strategic goal for governments seeking to manage the contradictory social demands that they face to try to involve the public in the reform and reduction of their public services. All liberal democratic governments with significant historical welfare states now face fundamental dilemmas of legitimacy precisely because, on the one hand, the public continues to demand more and better public services; while, on the other, capital has sought to reduce government expenditure on public services globally and to shift said funding out of the hands of the state and into that of the private sector (Hudson, 2012). Public participation becomes a means by which governments can attempt to legitimise the privatisation of and cuts in public services. To this end managers involved in such processes also develop mechanisms enabling them to avoid public responses if they are considered too contentious (Harrison and Mort, 1998, page 67).

The Coalition government have built on New Labour's legacy by calling for a return to ideas of voluntary work, self-help, and mutual aid in support of a 'Big Society' with a diminished state (Blond, 2010; Ham, 2010). The crucial distinction between the way in which Ward talks about self-help, mutual aid, and public services as opposed to the Coalition government's meaning of the terms is, as noted earlier, that for Ward they were principles and practices that led to public services outside the control of the state and the market and under the direct control of the communities that established them. Public participation is the actual running and maintaining of the very services that the public relied upon. For the Coalition government this cannot be the case. Rather, the meaning of mutual aid and selfhelp is to appeal to a natural and commendable public spiritedness that will help to bolster public services facing huge cuts in funding. The state, crucially, will always act to regulate such activities and, as Ward observed, is not in the habit of voluntarily dissolving itself for the public good (Ward, 1996c). As David Cameron has made clear, "we need to use the state to remake society" (Cameron, 2009; Woodhouse, 2013). Thus, the reconstitution of society is a top-down process rather than one which emanates from the bottom-up, which would be Ward's preference, of course. Therefore, for Cameron the emphasis is on the responsibilities of communities in partnership with the state rather than the rights of individuals and groups against the state - "a society where the leading force for progress is social responsibility, not state control" (Woodhouse, 2013). Indeed, the Tory Party, from which the idea of a Big Society emanates, has shown itself to be remarkably hostile to human rights in practice. Therefore, a new relationship is established whereby either as consumers or 'good citizens' the public are 
invited to participate as partners of the state and the market in the transformation of their own services (Alcock, 2004). On this point Ward follows Landauer's suggestion that:

"the state is not something which can be destroyed by a revolution, but is a condition, a certain relationship between human beings, a mode of human behaviour; we destroy it by contracting other relationships, by behaving differently" (cited in Ward, 1973, page 19). As a form of social relationship, the state has the capacity to reconstitute itself in complex ways, as it now doing with its transformation of the public services and the role that public participation plays within it. But it remains the state, nonetheless, with its modes of behaviour, rewards, punishments, and forms of coercion. However, and as will be shown in the next section in relation to working-class associations, the second part of Landauer's quote is equally important; it is these 'other relationships', built upon mutual aid and selfhelp, that offer an antistate and anticapitalist alternative understanding of public participation and public services. For much of the UK's radical left, the idea of a Big Society has been viewed with deep hostility (Seymour, 2010). However, looking at this development through Ward's pragmatic anarchism, it is possible to remain sceptical about the Big Society but also to recognise that it might create opportunities for individuals and communities to develop initiatives that genuinely challenge the state and the market around the provision of welfare. For example, Ward was not against the sale of council houses as pushed through by Conservative governments in the 1980s. What he wanted, though, was a far more radical approach to distributing council houses in the form of associations and cooperatives that would empower local communities at the expense of the state. Such a view was anathema to much of the traditional left in the UK who advocated what Ward called a form of 'municipal paternalism' whereby the state in the form of local government and the ruling political party viewed council houses as resources to be controlled for political ends rather than being a means to promote a freer (more anarchic and self-governing) society. A question that Ward might ask is: is it possible to use aspects of the Big Society to promote anarchic ends? As White (2010) observes, Ward's pluralistic conception of anarchism viewed it as being:

" any social space in which the techniques of mutuality predominate. It is a social space which people enter (and leave) freely; relate as equals; and do something creative. To solve a problem, meet a need, or just enjoy creativity for its own sake. And the aim of anarchism is to try to push and shove society in the direction of greater anarchy in this sense."

In practical terms, the difference between the Coalition government's ideas of a Big Society built on voluntarism, mutual aid, and self-help and Ward's can be illustrated by two examples. The idea of 'free schools' has proven to be an important policy for the Coalition government, as it offers parents the increased opportunity to oversee the running of their children's education. But in what sense are these schools free? They are still bound by the strictures of the National Curriculum and increasingly politicised Ofsted inspections to ensure conformity to a government determined norm (Helm and Boffey, 2014). They are free, then, to manage their own affairs within the context of a highly centralised national framework. There has been an alternative tradition of libertarian free schools in the UK, including those set up by working-class communities, but historically the state has been hostile to them and continues to be so in the extreme as the recent Ofsted court case against Summerhill free school illustrates (Shotton, 1993; Stronach, 2005). These schools are free in the sense that Milton famously described in his essay "Against Kings and Magistrates", where he distinguished between the free and those who choose to conform to the state, an account which resonates with Ward's view:

"but being slaves within doors, no wonder that they strive so much to have the public State conformably govern'd to the inward vitious rule, by which they govern themselves. 
For indeed none can love freedom heartily, but good men; the rest have not freedom, but license which never have more scope or more indulgence than under tyrants" (Milton, 1979 [1649], page 249).

Thus, free schools are 'free' only under license from the state, which uses a variety of mechanisms to discipline them into conforming to state-determined standards and educational content. They are not free to determine their own aims, content, or educational experiments.

However, the Big Society has also thrown up opportunities for individuals and communities to find ways to use the governments' policies for ends which are much more in keeping with Ward's ideas of a free society. For example, the government has sought to fund community initiatives around the UK in a reasonably open way, offering relatively small sums of money to promote community activism, provided that the recipients can match the government's investment with an equal sum. A community group in the Southwest has successfully secured funding in conjunction with a radical and independent trade union to effectively promote community unionism in their area. This entails organisers working street-by-street to talk to residents in deprived areas, those hit hardest by the Coalition cuts in public services, to establish a list of their needs and complaints in order to promote the idea that if they organise themselves they can work in partnership with the union to rebuild their communities, link their communities to their workplaces, and move towards freer and genuinely self-governing forms of community (interview, December 2013). These are the spaces within which people attempt to build a free society rather than a life under license from the state. Many anarchists would blanch at the idea of receiving any funding from the state, but we are confident that Ward would view this pragmatically as a way of enabling individuals and communities to shove and push freedom away from the state and the market and towards society. This, if you like, is Ward's Big Society-public participation, rather than that of the Coalition government.

Even so, most studies suggest that the government's attempt to mobilise public participation has proven to be at best a limited process with managers unsure how to deal with the public's ideas and with the difficulty to mobilise the public. So the appropriation of the language of mutual aid and self-help that Ward identifies has seen it become transformed into a vocabulary that uses the idea of the active and good citizen to attack the public aspect of the welfare state. The Coalition government is not against a welfare state per se, despite what many critics charge. On the contrary, they want a welfare state run by and in the interests of private companies, subsidised by public finance through taxation, forming, as Hudson (2012) notes, a natural private monopoly at public expense (see also The Big Society, 2014).

So models of public participation, whether consumer led or citizen led, are entirely in keeping with the discursive boundaries of liberal democratic societies; and, in practice, they guide and delegate a clear and limited role for the public (Beresford, 2002). The public can be consulted, or they can be partners, or they might even be in control of some decisions, but this is not against the state and the market (NHS, 2008, pages 33-41). On the contrary, it is in support of them in the guise of a newly constituted relationship. Having set out the limitations of the idea of public participation in liberal democracy, we can now turn to Ward's ideas on mutual aid and self-help in working-class communities for an alternative way of understanding the concept. 


\section{Mutual aid and self-help: the lost history of public services and a DIY culture}

"Social welfare can exist without the state"

Ward (1973, page 110)

Colin Ward saw mutual aid and self-help as principles and practices that were the natural response of working-class movements in 18th and 19th century Britain struggling to cope with the disastrous effects of industrialisation and capitalism on their daily lives. The mass of working people in the 19th and the early 20th centuries were hostile or at best indifferent to the welfare state because of a practical preference for self-help, independence, and mutual aid. For example, significant sections of the British working class were very hostile to the idea of a state-run national education system (Gardner, 1984; Shotton, 1993; Smith, 1983; Ward, 1995, page 11). The state was viewed as an institution by and for the rich (Thane, 1984, page 877). Out of the upheavals experienced in working-class communities in the 19th century, a whole array of associations emerged that enabled them to organise and provide the services they needed to render their lives more humane (Green, 1985, page 1). Friendly societies, notably, pioneered self-help and mutual aid amongst the working class (Gosden, 1961, page 7). For Ward, these associations were important in that they provided alternatives to the state and the market and were historical proof of the possibilities of Landauer's (2010) critique of the state. Public participation and public services were intrinsic to the nature of these associations, and not a right to be claimed against the state.

For Ward self-help is effectively a form of direct action; that is, the basis for the emergence of autonomous working-class institutions and movements to address the diverse problems, needs, and interests of their communities; Ward (1973, pages 28-37) referred to this as the 'spontaneous order'. To reiterate, the virtue of self-help was that it created a practical and independent working class which could create associations free of the direct control of the state or capital, a do-it-yourself culture. Workers were encouraged to join trade unions and fight for higher wages rather than depend upon the state for welfare (Thane, 1984, page 879). It was the psychological impact of such direct action that was crucial in instilling amongst working-class communities the belief and commitment needed to raise the quality of their lives through the creation of free and voluntary forms of association.

As a follower of the anarchist Kropotkin (2009; also McKay, 2011), Ward viewed mutual aid as a natural part of human evolution that describes how, in countless ordinary ways, cooperation is constitutive of social order and everyday life. Out of these natural forms of cooperation, we gain the things that we need in order to live. Though there was nothing inevitable about mutual aid being realised, the task was to create the associations that would encourage the most social aspects of the human character to thrive. Thus in his work Ward (1973) has provided rich historical and sociological accounts of, for example, the libertarian organisation of postal and railway services, and the squatters movement that arose in the 1960s and 1970s in Britain out of which emerged housing associations and cooperatives (Ward, 1990a, page 121). Importantly, and reiterating a point made earlier, Ward (1989, pages $80-85$ ) notes that the control of housing resources built tenants' confidence and led to their greater participation in community life.

\section{Mutual aid and self-help in the working-class associations}

Historically, perhaps the most important working-class associations were the highly successful friendly societies which allowed working-class communities to provide themselves with a variety of essential public services such as, in addition to housing, education, health, food, and leisure. In practice friendly societies embodied what Ward saw as our natural inclination to spontaneous order and organisation: they emerged to fulfil the social and communal needs of distinct communities (Gosden, 1973, page vii; Ward, 1973, pages 28-38). By the beginning of the 19th century, friendly societies were nationwide with a branch in every British town and 
usually several branches located in communities and directly accountable to their members. By 1900, membership of friendly societies equalled 5.65 million while trade unions (subject to anti-working-class laws) were 1.2 million (Thane, 1984, page 878 ). Friendly societies were the most important providers of social welfare in the 19th and 20th centuries in Britain (Weilbren and James, 2005, pages 95-96). They were models of self-governing fraternal association for the provision of mutual aid (Gorsky, 1988, page 502; Green, 1985, page 12; Thane, 1984). In addition, they were at the forefront of the development of democracy in the UK precisely because of the nature of their organisational structure: that they were member controlled, directly accountable, and built on fraternal relations (Weilbren and James, 2005, pages 95-96). They also provided early support to workers seeking to take industrial action against their employers and in the face of the long history of anti-trade-union laws in the UK. For all these reasons the state and the ruling class of the time rightly saw them as potentially a revolutionary and subversive threat to their interests (Gosden, 1961, page 156).

Ward (1996c) notes that, in the 19th century, health care for the working classes was largely shaped by membership of friendly societies which contracted doctors and nascent hospitals for their members. This included regulating their pay and conditions of work. The irony here was that most doctors were from the middle or upper middle classes and yet they were subject to direct control by working-class associations. This created much resentment on the part of the general practitioners, who were unhappy at having to be in the employ of their social inferiors (Gosden, 1961, pages 145-146). Part of the reason that doctors and the British Medical Association were actually in favour of the creation of the NHS was because it would enable them to control their profession, careers, and salaries and take them out of the employment of working-class communities (Green, 1985, page 108; Taylor, 2003, page 133; Thane, 1984). In the same way, the working classes sought to provide educational resources for their children that were more specific to the real lives that they lived rather than what was often seen as the indoctrination (and irrelevance) of state education. There are many accounts of parents and pupils rioting and striking against enforced education by the state which was often fiercely resented by the working class who distrusted the state and its motivations (Gardner, 1984; Heartfield, 2011; Humphries, 1981; Mason, 1973; Ward, 1996c, pages 79-88).

Friendly societies were not perfect and did not cover all of the working class by any means, something Ward acknowledges; yet they were also more consistent in their provision of services than critics have alleged. These forms of working-class associations emerged organically from within working-class communities and provided a path for the working classes in Britain through which they could take control of their own services. As plural and decentralised bodies, they were the antithesis of the centralising welfare state that ultimately came to replace them (Ward, 1973, pages 110-125). It was a very practical form of direct action as public participation that opposed the direction of industrial capitalism and the state, and they serve as a historical reminder of a forgotten idea in the UK about how public services could be produced outside of the state and the market.

The idea of autonomous working-class associations having control of services that were essential to their lives was clearly a revolutionary challenge to the ruling classes of the 19th and 20th centuries. Arguably up until the 1911 National Insurance Act, most working-class opinion was against state provision of health, welfare, and education for the obvious reason that the state was a representative of elite and ruling class interests, not those of the working class. The crucial factor in leading the working class into accepting a welfare state was the leadership of the trade union movement and the Labour Party who saw a form of municipal state socialism as the future for socialism in Britain. It was the emergence of these new elites drawn from the working class that underpinned the emergence of the welfare state, 
and which undermined many of the most important autonomous working-class associations (Thane, 1984, page 886). The decline of these particular working-class associations was a necessary part of the construction of the welfare state and the extension of the state into wider areas of social life, forming new kinds of hierarchical relationships with citizens and generating new modes of behaviour in health, education, housing, welfare. Even as major a figure in the history of the welfare state as Titmuss (1964) acknowledges that its emergence destroyed something of great value in working-class life. In short, it substituted fraternalism for paternalism. How can this be explained?

\section{The working class as partners of welfare state capitalism}

Ward's view is that while the established left in Britain was open to debate about the path to a socialist future for much of the 19th and early 20th centuries, by the time of the Russian Revolution the choice of state socialism was settled. In the UK this was to be the Fabian municipal socialism and welfare state that would effectively erase autonomous workingclass associations in the form that they had taken. The influence of the Russian Revolution seems to have been decisive here, initially suggesting a state-led path to socialism before the real nature of Bolshevism was revealed in practice. In so doing the British left abandoned ideas that Ward saw as being a part of any libertarian socialist future. The working class lost control over their services, however uneven and imperfectly delivered, in return for a dependency upon a welfare state organised by the professions that ran it in part as a way of protecting their own interests against those of the working class (Ward, 1973, page 18). As Ward notes, "states, both on the continent and in these islands, systematically weeded out all institutions in which the mutual aid tendency had formerly found its expression" (page 111).

Ward argues that the welfare state is antithetical to the kind of mutual aid and self-help that is found in working-class associations. In Tenants Take Over (1974) he illustrates this with a brief extract from a booklet provided to council house tenants in the 1950s, early recipients of the new welfare state largesse:

"Keep your home clean and tidy. Endeavour to have some method of cleaning as you go along; do not try to clean the whole house in one day. Regular bed times for children and adults, except on special occasions. Sit down properly at the table. Hang up your pots and pans or put them on a shelf"' (page 12).

This conveys the limitations of municipal and bureaucratic state provision as a form of social control and moral regulation of the working class (Humphries, 1981, pages 14-20). Equally, when the Marxist party Militant became powerful in the running of Liverpool city council between 1983 and 1987, they turned cooperative-designed and self-run housing into old-style council houses under their control, not that of the tenants.

The working-class associations have largely been transformed into partners or extensions of welfare state capitalism, such as the trade union movement itself. Ward (1973) quotes the former Labour Party Minister Anthony Crosland, who said that "the greater the power of the unions [in partnership with the state] the less the interest in workers' management" (page 97). The radicalism of such movements has been replaced by a corporate and corporatist ethos that renders them business unions selling services to their members and selling their members to employers in return for the best deal they can cut, rather than vehicles for radical social change (Ewing, 2005). And, as the recent Trade Union Congress rally against austerity in October 2012 revealed, the Trade Unions literally work with the state to regulate and control the actions of their members lest anything happen that they cannot control - a very clear example of the meaning of public participation in current British political culture, an elite-led and guided democratic process (Freedom 2012). 
To reiterate, what Ward describes is a tendency in history towards free and voluntary social arrangements that have the potential to direct social life towards the end goals of a free (anarchist, in Ward's terms) society which he defines by quoting Kropotkin as:

"the name given to a principle or theory of life and conduct under which society is conceived without government - harmony in such a society being obtained, not by submission to law, or by obedience to any authority, but by free agreements concluded between various groups, territorial and professional, freely constituted for the sake of production and consumption, as also for the satisfaction of the infinite variety of needs and aspirations of a civilised being" (Ward, 2003, page 25).

The problem facing such free and voluntary relations and forms of organisation is that they always face the danger of being co-opted by the state and/or the market, both of which exist by dint of their power to take over forms of social life that attempt to exist outside of their authority. We need to be cautious here, though, and not see this process of co-optation as inevitable or totalising in the way that certain strains of Marxist thought have come to do. The point that Ward is making forcefully is that, even in undemocratic states and where people are subject to the most rapacious capitalist markets, these mechanisms cannot, in the end, subordinate social life totally to their logic. On the contrary, social life always persists in free, autonomous, and voluntary manner, in diverse ways, and these impulses amongst people rise up in even the most unpromising of environments (White, 2014). Contemporary examples serve to illustrate Ward's point; they are far from being exhaustive, of course. Not all of these are presented as being examples of anarchist activities. Rather, they are examples, large and small, of groups and individuals that have sought to use the principles that Ward sets outdirect action, self-help, voluntary activity, and mutual aid - in order to achieve their goals. In this sense they reflect Ward's alternate idea of a public and the provision of welfare that is not provided by either the state or the market:

(a) Welfare

There are many contemporary examples of groups which have sought to promote their own welfare in diverse ways. Zubechi $(2010 ; 2012)$, for example, has extensively covered social movements in South America since the 1980s and the ways in which they have sought to organise themselves by seizing land from the state or absentee landowners in order to build communities with social services, from housing to energy and water supplies, through to education and forms of entertainment. In the UK one can note the regular emergence of social movements around the issue of welfare whenever it is threatened by the state or the market, from the anti-poll tax campaign to the current campaign against the 'bedroom tax'. In Italy the now well-known proliferation of 'social centres' emerging out of the anarchist and autonomist Marxist movements of the 1970s have evolved into multifaceted organisations providing everything for their members from venues for music to welfare advice and support for immigrants, the homeless, and prostitutes, all free and voluntary, reflecting solidarity, self-help, and mutual aid (Gautney, 2009, page 483).

(b) Environment

Environmental groups have grown massively in the Global North since the 1970s, as Ward often noted, and represent many ways in which individuals, groups, and communities have sought to protect their natural and social environment from threats usually generated by corporations or the state. Reclaim the Streets is a good example of this and is one which has clear ideological links to anarchism. It has gone from being a British community of activists linked by a desire to defend public spaces and challenge pollution caused by cars to being a global movement (largely in the Global North) that has launched protests and street parties around the world and tried to build community gardens in cities, free for anyone to use. 
(c) Work

Work was a persistent theme in Ward's writings, distinguishing as he did between employment (usually the drudgery of working in unsatisfying jobs for an employer) as opposed to work (doing things; making things for ourselves and our friends). Trade unions remain at the forefront of the efforts of workers and nonworkers alike to civilise the production of the goods and services that they need in order to live. Rank-and-file initiatives are the kind that anarchists such as Ward advocate-grassroots movements which are often in conflict with the union structures in which they operate. They have been at the forefront of the recent revival of trade unions in sectors of the economy that have hitherto been outside the organising capacity of trade unions: fast-food workers, domestic workers, cleaners, and janitors. Such initiatives draw upon the themes of self-organisation, often voluntary, built on solidarity and mutual aid. Examples include the emergence of unions for fast-food workers, Starbucks workers, and domestic workers (http://www.domesticworkersunited.org/index.php/en/, http:// www.starbucksunion.org/) (Christiansen, 2009, page 393). Anarchist and syndicalist unions and principles persist in the practices of many independent unions and have become a part of the resurgence of more militant mainstream trade union activities around the world. Such libertarian unions have always had more than just a concern with the workplace, and as Christiansen (2009) notes of the Industrial Workers of the World are best seen as social movements that connect communities with a broader social vision to transform the world. A good example of this can be found in the Federacao Anarquista Gauche Union in Brazil, which has been active working with neighbourhood popular committees in organising for local need provision in barrios. This covers such things as dealing with rubbish and extending education to people normally deprived of it (Shantz, 2009, page 374). Crucially, this is an example of anarchists in action, to borrow Ward's phrase, working with communities rather than trying to take them over or lead them in instrumental manner.

\section{(d) Consumption}

Ward was concerned with the ways in which we can consume the things we need in order to challenge or mitigate the effects of corporate and state control of the production process. There are many excellent examples of initiatives in the UK alone that embrace Ward's principles (voluntary, free, self-help, mutual aid, and so on). Freecycle is a website that enables people to match objects they no longer use with people that need them, for free exchange. In similar fashion the Local Exchange Trading System (or LETS) has now become a global federation of not-for-profit community groups that are based on a form of mutual credit, enabling people to swap goods or earn credit to spend in the local LETS through offering services such as babysitting. As with Freecycle, LETS are grassroots and democratically organised models of community action.

What these examples have in common is a commitment to the principles underpinning the idea of the public that Ward sets out: voluntary, direct action, mutual aid, and self-help. This does not necessarily make them 'anarchist' movements, but it does mean that they are drawing from the same conceptual sources.

This desire for free association is something that successive governments in the UK have sought to exploit in their reform of the public services. They have found, unsurprisingly, that it is very difficult to simply graft these modes of behaviour onto existing state and market institutions. The reason that these earlier working-class associations in Britain were able to function and produce the solidarity that they did was precisely because they had been created and controlled by the people who used them. The welfare state does not have this history and cannot simply reinvent it in instrumental fashion. Appropriating the libertarian language that Ward describes (self-help, mutual aid, direct action, or social solidarity) may or may not reflect genuine ideological commitment on the part of the major British 
political parties, but it does not mean the hollowing out of the state, as some writers have suggested. Rather, it is itself a new state strategy and relationship for mobilising the public in support of the privatisation of public services by using decentralisation as a method for co-opting and empowering communities to impose cuts and privatisation upon their own services (Sullivan et al, 2004, pages 245-246).

\section{Conclusion: reforming the public services}

Ward's critique of the welfare state and liberal democratic ideas of public participation are important for a number of reasons. First, they highlight the instrumental nature of recent and current government policy towards public participation in the reform of the public services. The embrace of libertarian concepts of self-help and mutual aid and voluntary or free association by Britain's political parties is limited by the parameters of liberal democratic discourse and its representative form of government. Thus the debate between consumerled and citizen-led approaches to public participation is not the dichotomous contrast that it might appear to be for many of its proponents but falls within the normal parameters of liberal democratic discourse. The public is viewed ultimately in instrumental terms as something to be mobilised and guided by the choices offered by either the state or through the market.

The second point to emerge from Ward's work is that the realm of anarchy, as he describes it, is not a future ideal but part of everyday life because it refers to ways in which people freely associate to pursue their interests in a manner that combines self-help and mutual aid. These are, Ward insists, virtuous principles and practices and wherever they can be extended in social life is to the benefit of a free society. The biggest obstacle to this is that the nature of British liberal democracy, as noted earlier, rests upon complex forms of social relationship and hierarchy that are structured in such a way as to deny or co-opt autonomous workingclass activities and by extension the control of resources and services. This is a fundamental antagonism and fault line in British society. It is against this tendency that individuals and their communities have to fight in order to control the resources and services that they need. The welfare state, however benevolent the intentions of its founders may have been, has in practice also served as a relationship of enclosure of autonomous working-class associations, and in so doing it has transformed the meaning of public participation from being something intrinsic to these associations into an instrumental relationship constructed by the state, the market, or both.

The final point to note is that the associations that Ward describes cannot, of course, be brought back to life in their previous form. They were of their time and place. But the principles and practices that made them such powerful organisations still persist, as Ward also makes clear and as we have shown in this paper. To this end we have set out a number of examples of contemporary autonomous activities taking place around the world that reflect the principles Ward describes. And importantly, engaging with Ward's work illustrates the ways in which the libertarian language of mutual aid, self-help, and voluntary association have been co-opted by political parties in debates over public participation, for quite different ends. The ongoing reform of public services and cutbacks in welfare provision suggest that the need for new associations based on such principles will increase as successive governments attempt to shift the costs of the financial crisis onto the shoulders of the working population (Hudson, 2012).

\section{References}

Alcock P, 2004, "Participation or pathology: contradictory tensions in area-based policy" Social Policy and Society 3 87-96

Baggott R, 2005, "A funny thing happened on the way to the forum? Reforming patient and public involvement in the NHS in England" Public Administration 83 533-551

Barnes M, 1999, "Researching public participation" Local Government Studies 25 60-75 
Barnes M, Knops A, Newman J, Sullivan H, 2004, "Recent research: the micro-politics of deliberation" Contemporary Politics 10 93-100

Barnes M, Newman J, Knops A, Sullivan H, 2003, "Constituting 'the public' in public participation" Public Administration 81 379-399

Barnes M, Newman J, Sullivan H, 2006, "Discursive arenas: deliberation and the constitution of identity in public participation at a local level" Social Movement Studies 5 193-207

Beresford P, 2002, "User involvement in research and evaluation: liberation or regulation?" Social Policy and Society 1 95-105

Bernays E, 2004 Propaganda (Ig Books, New York)

Big Society, 2014, “We are the Big Society”, http://www.the-big-society.co.uk/

Blond P, 2010 Red Tory (Faber and Faber, London)

Bochel C, Bochel H, Somerville P, Worley C, 2007, "Marginalized or enabled voices? 'User participation' in policy and practice" Social Policy and Society 7 210-201

Bradshaw P, 2008, "Service user involvement in the NHS in England: genuine user participation or a dogma driven folly?" Journal of Nursing Management 16 673-681

Burnham P, 2001, "New Labour and the politics of depoliticisation" British Journal of Politics and International Relations 3 127-149

Cameron D, 2009, "The Big Society", http://www.respublica.org.uk/item/ResPublica-mentioned-in-Camerons-speech-ggtc

Christiansen J, 2009, “'We are all leaders': anarchism and the narrative of the I.W.W." WorkingUSA: The Journal of Labor and Society 12 387-401

Clarence E, Painter C, 1998, "Public services under New Labour: collaborative discourses and local networking" Public Policy and Administration 12 8-22

Clarke J, 2005, "New Labour's citizens: activated, empowered, responsibilized, abandoned?" Critical Social Policy 25 447-463

Cohen S, 1985 Visions of Social Control (Polity Press, Cambridge)

Conrad E, Cassar L, Christie M, Fazey I, 2011, "Hearing but not listening? A participatory assessment of public participation in planning" Environment and Planning C: Government and Policy 29 761-782

Corner J, Pels D, 2008 Media and the Restyling of Politics: Consumerism, Celebrity and Cynicism (Sage, London)

Crouch D, Ward C, 1997 The Allotment: Its Landscape and Culture (Five Leaves Publications, Nottingham)

Davies A, 2002 Public Relations Democracy: Politics, Public Relations and the Mass Media in Britain (Manchester University Press, Manchester)

Design Council, 2007 Design Blueprint, http://www.designcouncil.org.uk/Documents/Documents/Publications/Design\%20Blueprint_ Design_Council.pdf

Doyal L, 1998, "Public participation and the moral quality of health care" Quality in Health Care $198-102$

Edwards N, 2006, “The transparent NHS?” AIMS Journal 18, http://www.aims.org.uk/Journal/Nol18No4/transparentNHS.htm

Ewing K D, 2005, "The function of trade unions" Industrial Law Journal 34 1-22

Exworthy M, Halford S, 1999 Professionalism and the New Public Management (Open University Press, Milton Keynes, Bucks)

Fones-Wolf E, 1995 Selling Free Enterprise: The Business Assault on Labor and Liberalism: 1945-60 (University of Illinois Press, Champaign, IL)

Freedom 2012, "The TUC: state lackeys", 79 October

Fung A, 2006, "Varieties of participation in complex governance" Public Administration Review 66 66-75

Gardner P, 1984 The Lost Elementary Schools of Victorian England (Croom Helm, Beckenham, Kent)

Gautney H, 2009, "Between anarchism and autonomist Marxism" WorkingUSA: The Journal of Labor and Society 12 467-487

Goode L, 2005 Jurgen Habermas: Democracy and the Public Sphere (Pluto Press, London)

Goodway D, 2012 Anarchist Seeds Beneath the Snow (PM Press, Oakland, CA) 
Gorsky M, 1988, "The growth and distribution of Friendly Societies in the early C19" Economic History Review 1 489-511

Gosden P H J H, 1961 The Friendly Societies in England 1815-1875 (Manchester University Press, Manchester)

Gosden P H J H, 1973 Self-Help: Voluntary Associations in 19th century Britain (B T Batsford, London)

Green D, G, 1985 Working Class Patients and the Medical Establishment: Self-Help in Britain from the Mid-Nineteenth Century to 1948 (Maurice Temple Smith, London)

Ham C, 2010, "The coalition government's plans for the NHS in England" British Medical Journal $341 \mathrm{c} 3790$

Harrison S, Mort M, 1998, "Which champions, which people? Public and user involvement in health care as a technology of legitimisation" Social Policy and Administration 32 60-70

Heartfield J, 2011, "Where they teach you how to be thick", http://libcom.org/library/where-they-teach-you-how-be-thick-james-heartfield

Helm T, Boffey D, 2014, "Angry LibDems accuse Michael Gove of bid to politicise Ofsted" The Observer, http://www.theguardian.com/politics/2014/feb/01/coalition-split-gove-bid-politicise-education

Hind D, 2010 The Return of the Public (Verso, London)

Honeywell C, 2007, “Utopianism and anarchism” Journal of Political Ideologies 12 239-254

House of Commons Health Committee, 2007 Patient and Public Involvement in the NHS: 3rd Report of Session 2006-07, http://www.publications. parliament.uk/pa/cm200607/cmselect/cmhealth/278/278i.pdf

Hudson M, 2012 Finance Capitalism and its Discontents (ISLET Publishers, New York)

Humphries S, 1981 Hooligans or Rebels? An Oral History of Working-class Childhood and Youth: 1889-1939 (Basil Blackwell, Oxford)

Innes J, Booker D, 2004, "Reframing public participation: strategies for the C21" Planning Theory and Practice 5 419-436

Kropotkin P, 2009 Mutual Aid: A Factor of Evolution (AK Press, Edinburgh)

Landauer G, 2010 Revolution and other Writings (PM Press, Oaklands, CA)

Lane J E, 2000 New Public Management (Routledge, London)

Lasswell H, Lerner D, 2011 The Comparative Study of Elites (Literary Licensing, New York)

Lewis J, Inthorn S, Wahl-Jorgensen K, 2005 Citizens or Consumers? The Media and the Decline of Public Participation (Open University Press, Milton Keynes, Bucks)

Lippmann W, 2010 Public Opinion (BN Publishing, New York)

Litva A, Coast J, Donovan J, Eyles J, Sheperd M, Tacchi J, Abelson J, Morgan K, 2002, "The public is too subjective: public involvement different levels of healthcare decision-making" Social Science and Medicine 54 1825-1837

Lowes L, Hulatt I (Eds), 2005 Involving Service Users in Health and Social Care Research (Routledge, London)

Lowndes V, Sullivan H, 2004, "Like a horse and carriage or a fish on a bicycle? How well do local partnerships and public participation go together?" Local Government Studies 30 51-73

Lowndes V, Pratchett L, Stoker G, 2001, "Trends in public participation: part 2-citizens' perspectives" Public Administration 79 445-455

Lowndes V, Pratchett L, Stoker G, 2006, "Diagnosing and remedying the failings of official participation schemes: the CLEAR framework" Social Policy and Society 5 281-291

McKay I, 2011 Mutual Aid: An Introduction and Evaluation (AK Press, Edinburgh)

Marden P, 2003 The Decline of Politics: Governance, Globalisation and the Public Sphere (Ashgate, Aldershot, Hants)

Martin G, 2008, “' Ordinary people only’: knowledge, representativeness and the publics of public participation in healthcare" Sociology of Health and Illness 30 35-54

Mason D, 1973, “Children's strikes in 1911”, http://libcom.org/history/childrens-strikes-1911

Michels R, 2001 Political Parties: A Sociological study of the Oligarchical Tendencies of Modern Democracies, http://etext.lib.virginia.edu/toc/modeng/public/MicPoli.html

Mills C W, 1999 The Power Elite (Oxford University Press, Oxford) 
Milton J, 1979 [1649] Selected Prose (Penguin Books, Harmondsworth, Middlesex)

Moloney K, 2006 Rethinking Public Relations: PR Propaganda and Democracy (Routledge, London)

Mosca G, 2011 The Ruling Class (Lightning Sources Books, London)

Newman J, Barnes M, Sullivan H, Knops A, 2004, "Public participation and collaborative governance" Journal of Social Policy 33 203-223

NHS, 2008, "Next stage review: high quality care for all", http://www.dh.gov.uk/prod_consum_dh/groups/dh_digitalassets/@dh/@en/documents/digitalasset/ dh_085828.pdf

Niebuhr R, 2005 Moral Man and Immoral Society (Continuum, New York)

Orme J, Powell J, Taylor P, Grey M, 2003 Public Health for the 21st Century: Perspectives on Policy, Participation and Practice (Open University Press, Milton Keynes, Bucks)

Rowe G, Frewer L, 2004, "Evaluating public participation exercises: a research agenda" Science, Technology and Human Values 29 512-556

Rowe R, Shepherd, M, 2002, "Public participation in the new NHS: no closer to citizen control?" Social Policy and Administration 36 275-290

Scammell M, 2008, "Citizen consumers: towards a new marketing of politics?", in Media and the Restyling of Politics. Consumerism, Celebrity and Cynicism Eds J Corner, D Pels (Sage, London) pp 117-136

Scott J, 2012 Two Cheers for Anarchism (Princeton University Press, Princeton, NJ)

Seymour R, 2010 The Meaning of David Cameron (Zero Books, London)

Shantz J, 2009, "Anarchy in the unions: contemporary anarchists at work" WorkingUSA: The Journal of Labor and Society 12 371-385

Shantz J, 2013 Commonist Tendencies: Mutual Aid beyond Communism (Punctum Books, Brooklyn, $\mathrm{NY}$ )

Shotton J, 1993 No Master High or Low: Libertarian Education and Schooling in Britain 1890-1990 (Libertarian Education, Bristol)

Smith M, 1983 Libertarians and Education (Allen and Unwin, London)

Stronach I, 2005, "On Her Majesty’s Disservice: HMI and Summerhill School”, http://www.iiqi.org/C4Ol/httpdocs/qi2005/papers/stronach.pdf

Sullivan H, Knops A, Barnes M, Newman J, 2004, "Central-local relations in an era of multi-level governance: the case of Public Participation policy in England: 1997-2001" Local Government Studies 30 245-265

Taylor M, 2006, "Communities in partnership: developing a strategic voice" Social Policy and Society $5269-279$

Taylor P, 2003, “The lay contribution to public health", in Public Health for the 21st Century: Perspectives on Policy, Participation and Practice Eds J Orme, J Powell, P Taylor, M Grey (Open University Press, Milton Keynes, Bucks)

Thane P, 1984, "The working class and state welfare in Britain: 1880-1914" The Historical Journal $27877-900$

Titmuss R, 1964, "The limits of the welfare state" New Left Review, http://newleftreview.org///27/richard-titmuss-the-limits-of-the-welfare-state

Tucker A, 2004, "The role of reflexive trust in mediating public administration" Public Performance and Management Review 28 53-74

Ward C, 1973 Anarchy in Action (Allen and Unwin, London)

Ward C, 1974 Tenants Take Over (The Architectural Press, London)

Ward C, 1985, When we Build Again: Let's Have Housing That Works (Pluto Press, London)

Ward C, 1987, "The case against voting" New Society, http://theanarchistlibrary.org/library/colin-ward-the-case-against-voting

Ward C, 1988 The Child in the Country (Robert Hale, London)

Ward C, 1989 Welcome, Thinner City (Bedford Square Press, London)

Ward C, 1990a Talking Houses (Freedom Press, London)

Ward C, 1990b The Child in the City (NCVO Publications, London)

Ward C, ...., Influences: Voices of Creative Dissent (Green Books, Bideford)

Ward C, 1995 Talking Schools (Freedom Press, London) 
Ward C, 1996a Talking to Architects (Freedom Press, London)

Ward C, 1996b, "Anarchism and the informal economy", in Reinventing Anarchy, Again

Ed. H Ehrlich (AK Press, Edinburgh), pp ...-...

Ward C, 1996c, "The welfare road we failed to take", in his Social Policy: An Anarchist Response (Freedom Press, London)

Ward C, 2002 Cotters and Squatters: The Hidden History of Housing (Five Leaves Publications, Nottingham)

Ward C, 2003 Talking Anarchy: An Interview with David Goodway (Five Leaves Press, Nottingham)

Ward C, 2004 Anarchism: A Very Short Introduction (Oxford University Press, Oxford)

Ward C, 2011a, "Anarchism as a theory or organisation", in Autonomy, Solidarity, Possibility: The Colin Ward Reader Eds C Wilbert, D White (AK Press, Edinburgh) pp 47-55

Ward C, 2011b, "The future of the design professions", in Autonomy, Solidarity, Possibility: The Colin Ward Reader Eds C Wilbert, D White (AK Press, Edinburgh) pp 129-132

Ward C, 2012 Talking Green (Five Leaves Publications, Nottingham)

Ward C, Hardy D, 2003 Arcadia for All: The Legacy of a Makeshift Landscape (Five Leaves Publications, Nottingham)

Ward C, Hardy D, 2010 Goodnight Campers!: The History of the British Holiday Camp (Five Leaves Publications, Nottingham)

Weilbren D, James B, 2005, "Getting a grip: the role of Friendly Societies in Australia and Britain reappraised" Labour History 88 86-103

White S, 2007, "Making anarchism respectable? The social philosophy of Colin Ward" Journal of Political Ideologies 12 11-28

White S, 2010, "Colin Ward: pioneer of mutualism" Next Left: A Fabian Society Blog, http://www.nextleft.org/2010/02/colin-ward-pioneer-of-mutualism.html

White S, 2011, "Social anarchism, lifestyle anarchism and the anarchism of Colin Ward" Anarchist Studies 19 92-103

Williams C, Windebank J, 2000, "Self-help and mutual aid in deprived urban neighbourhoods: some lessons from Southampton" Urban Studies 37 127-147

Woodhouse J, 2013, "The voluntary sector and the Big Society", House of Commons Library, http://www.parliament.uk/business/publications/research/briefing-papers/SN05883/the-voluntarysector-and-the-big-society

Zubechi R, 2010 Dispersing Power: Social Movements as Anti-State Forces (AK Press, Edinburgh)

Zubechi R, 2012 Territories in Resistance: A Cartography of Latin American Social Movements (AK Press, Edinburgh) 